\title{
Hirudoterapi ve Cerrahide Kullanımı
}

\author{
Hirudotherapy and Use in Surgery
}

\author{
Gülay Trak \\ Sakarya Üniversitesi Eğitim Araştırma Hastanesi Klinik Mikrobiyoloji AD, SAKARYA \\ Yazı̧̧ma Adresi / Correspondence: \\ Dr. Gülay Trak \\ Sakarya Üniversitesi Eğitim Araştırma Hastanesi Klinik Mikrobiyoloji AD, SAKARYA \\ E-mail: gulaysimsek80@gmail.com
}

Orcid

Gülay Trak : https://orcid.org/0000-0002-4120-7249

Geliş Tarihi / Received : 15-02-2019

Kabul Tarihi / Accepted : 28-04-2019

Yayın Tarihi / Online Published: 30-09-2019

Trak G. Hirudoterapi ve Cerrahide Kullanımı, J Biotechnol and Strategic Health Res. 2019;3(Özel Sayı):47-54 DOI: bshr.527435

Sülükler ile tedavi (Hirudoterapi), yüzyllar boyunca hastalar tarafından kullanılmış, enflamatuar hastalıklar, osteoartrit veya cerrahi sonrası gelișen komplikasyonlar üzerindeki muhtemel etkileri birçok araştırmacı tarafından da incelenmişve denenmiştir. Sülük tedavisinin kullanılabileceği endikasyonların başında plastik ve rekonstrüktif cerrahi operasyonlarında serbest ve pediküllü flep uygulamalarında post operatif gelișen venöz yetersizlikler gelir. Özellikle serbest flep uygulamalarında venöz problemler arteryel problemlere oranla çok daha sık görülmektedir. Hirudoterapi, venöz yetersizlik tedavisinde cerrahi eksplorasyona iyi bir alternatif oluşturmaktadır. Avrupa tıbbi sülük türlerinden olan Hirudo medicinalis, birçok hekim tarafından, daha küçük olması, yüzeysel kesik meydana getirmesi ve daha az kan emmesi nedeni ile özellikle tercih edilmektedir. Sülüklerin tükürük bezlerindeki salgılarında 100'ün üzerinde farklı özelliklere sahip biyoaktif maddeler vardır. Bu salgılar vazodilatasyona, analjeziye, antienflamasyona, kanda antikoagülasyonun arttırlmasına, bakteriyel çoğalımın engellenmesine, ödemin çözülmesine, mikrosirkülasyonun hızlanmasına, organ ve dokuların hasarlı vasküler yapılardaki permeabilitenin ve canlılı̆̆ın tekrar artmasına, hipoksinin düzeltilmesine, kan basıncının düşürülmesine, ağrının azaltılmasına ve immünitenin tekrar arttırmasına etkili oldukları gösterilmiştir. Tekniği ucuz, etkili ve kullanımı kolaydır. ABD İlaç ve Gıda Dairesi (Food and Drug Administration of USA-FDA) sülüklerin satıșına, genel amaçlı ve plastik cerrahi ve mikrocerrahide kullanımına 2004 yılında izin vermiștir. Türkiyéde de sülük uygulaması ile beraber onaltı uygulamayı kapsayan “Geleneksel ve Tamamlayıcı Tıp Uygulamaları Yönetmeliği” 2014’de yürürlüğe girmiștir.

Geleneksel tıpta uzun bir geçmiși olan sülük tedavisini uygulaması kolay, yan etkileri az ve uygun maliyettedir. Son yıllarda hem ülkemizde hem de dünyada modern tıp alanında yerini almaya başladığı görülmekte ve tedavilerde etkinliği arttırdığı görüldükçe kullanım alanları genişleyecektir.

Anahtar

Biyoaktif maddeler, hirudoterapi, sülük, rekonstrüktif cerrahi.

Abstract

Treatment with leeches (hirudotherapy), used by patients for centuries, the possible effects on inflammatory diseases, osteoarthritis or complications after surgery have been examined and tested by many researchers. One of the indications that leech therapy can be used is the postoperative venous insufficiency in free and pedicled flap applications in plastic and reconstructive surgery operations. Especially in free flap applications, venous problems are more common than arterial problems. Hirudotherapy is a good alternative to surgical exploration in the treatment of venous insufficiency. Hirudo medicinalis, one of the European medicinal leech species, is especially preferred by many physicians because of its smaller, superficial cuts and less blood sucking. There are over 100 different bioactive substances in salivary glands of leeches. These secretions have been shown to be effective in vasodilatation, analgesia, antiinflammation, increased anticoagulation in blood, inhibition of bacterial growth, dissolution of edema, acceleration of microcirculation, reorganization of organ and tissues in permeability and viability of damaged vascular structures, correction of hypoxia, reduction of blood pressure, reduction of pain and increase of immunity. The technique is cheap, effective and easy to use. The US Food and Drug Administration of the USA (FDA) in 2004, the sale of leeches, general-purpose and plastic surgery and microsurgery use in 2004 allowed. Turkey also covers the application along with sixteen leeches application "Regulation on Traditional and Complementary Medicine Practice" was enacted in 2014.

Leech therapy with a long history in traditional medicine is easy to apply, side effects are low and cost effective. In recent years, it is seen that it has started to take its place in modern medicine both in our country and in the world.

Keywords Bioactive substances, hirudotherapy, leech, reconstructive surgery. 


\section{Giriş}

Sülük sekresyonlarında farklı moleküler kütlelere ve özelliklere sahip 100'den fazla partiküler yapıda protein bulunmaktadır. Sülük ile tedavide (Hirudoterapi), bu proteinlerin çeşitli biyolojik özelliklerinden faydalanılır. Günümüzde sülüklerde bulunan bu aktif maddeler üzerine yapılan bilimsel çalışmalar bizlere bu proteinlerin nasıl çalıştıklarını anlamamıza yardımcı olmaktadırlar. Tanımlanabilmiş olan bu proteinlerin etki mekanizmaları arasında trombosit fonksiyonlarının inhibe edilmesi, antikoagulan etki, kan akışının hızlanması, antimikrobiyal aktivite göstermeleri, ekstraselüler matriks yıkımı, analjezik ve antienflamatuar etkiler sayılabilir. ${ }^{1}$

Sülüklerin klinik uygulamalarda kullanımları son yıllarda artmıştır. Cerrahi branşlarda primer endikasyonu venöz tıkanıklıklardır. Venöz konjesyonun cerrahi olarak düzeltilmesinin mümkün olamadığı veya başarısız olunduğu durumlarda, nekroz gibi gelişebilecek komplikasyonları önlemek için yeni damarlar gelişene kadar tıbbi sülüklerin etkilenen dokuların drenajını sağlamasından yararlanılabilinir. Ayrıca diğer klinik endikasyonları arasında variköz venler, kardiyovasküler hastalıklar, tromboflebit, osteoartrit, diş eti problemleri, cilt hastalıkları da sayılabilir. ${ }^{1,2}$

Hirudoterapi, bazı hastalıkların tedavisi için alternatif değil, tamamlayıcı ve / veya bütünleştirici bir tedavi seçimidir. Tekniği gayet ucuz, etkili ve kullanımı kolaydır.

Modern sülük tedavisi eski tedavilerden farklıdır; günümüzde hastalar belirli protokoller ile tedavi edilmekte ve sadece Gıda Tarım ve Hayvancılık Bakanlığı'nca ruhsatlandırılmış çiftliklerde yetiştirilen sülükler tedavi için kullanılmaktadır. Yabani sülükler kesinlikle kullanılmamakta, tıbbi sülükler de tek bir hasta için kullanılmakta, kullanım sonrası imha edilmektedir.

Bu derlemede, Geleneksel ve Tamamlayıcı Tibbın bir dalı olan Hirudoterapi hakkında bilgilendirme yapılması ve plastik ve rekonstrüktif cerrahide kullanımı hakkında bilgi verilmesi amaçlanmıştır.

\section{Sülük Salgısında Bulunan Biyoaktif Maddeler}

Tıbbi bir sülükte tükürük bezleri 100'den fazla biyoaktif madde içerir ve bu biyoaktif maddeler ödem azaltıcı, bakteriyostatik ve analjezik etkiye sahiptirler. Bu özellikleri ile mikro sirkülasyon bozukluklarını onarır, doku ve organların hasarlı damar geçirgenliğini geri kazandırır, hipoksiyi ortadan kaldırır, kan basıncını düşürür, bağışıklık sisteminin aktivitesini arttırır, enfarktüs ve felç gibi ciddi komplikasyonları engeller ve organizmanın biyoenerjetik durumunu iyileştirirler. ${ }^{2}$ Hastaya ve tedavinin amacına bağlı olarak her tedavi seansı için 1ile 5 sülük kullanılır. Isırma alanı, her 3-4 saatte bir, lokal olarak oluşan pihtıları gidermek için fizyolojik su ile temizlenir ve kanın sızma süresini artırmak için heparinli (5.000 U / ml) gazlı bezle temizlenir. Kullanılmış sülükler aynı hastada bile tekrar kullanılmaz, kullanılmış olan sülükler \%70 etil alkolde öldürülür ve tıbbi atık kutularına atılır. Sülük tükürüğün en önemli bileşeni trombinin inhibitörü olan Hirudin'dir. Hirudin, 65 amino asitten oluşur. Bu amino asitler, düzenli üç disülfit bağı içeren $\mathrm{N}$-terminal tarafı ve protein denatüre edildiğinde tamamen düzensiz olan bir C-terminal bölümünden oluşur. C-terminal tarafı, trombinin anyon bağlayıcı kısmı ile çok sayıda elektrostatik etkileşimler meydana getirir. Thrombin, pıhtılaşma panelinde birçok etkiye sahip olan bir koagülasyon proteinidir. Çözünür fibrinojeni çözünmeyen fibrin dimerlerine dönüştüren ve aynı zamanda diğer birçok pıhtılaşma ile ilgili reaksiyonu katalizleyen bir serin proteazdır. Hirudin, kumadin (warfarin) ve heparin gibi iyi bilinen diğer ilaçların aksine, son basamaktaki fibrinojenin fibrine dönmesini sağlayan trombine doğrudan bağlanarak etkisini gösterir. Warfarin, pıhtılaşma panelinde önemli rol oynayan $\mathrm{K}$ vitamininin işlevlerini inhibe ederek etkisini gösterdiğinden pıhtılaşma panelinde birçok basamakta etkilidir. Hirudin, bir ilaç olarak doğrudan ve sadece trombini inhibe ettiği için, warfarinin sahip olduğu olası kanamaların olumsuz yan etkilerine sahip olmamaktadır1. Hirudin, hem serbest hem de pıhtıya bağlı trombini inhibe etmesinin yanı sıra 
fibrinin parçalanması ile oluşan ürünler üzerinde de etkilidir. Rekombinant biyoteknoloji ile, doğal hirudinin aksine Tyr-63'teki sülfat grubu çıkarılarak rekombinant hirudin (r-hirudin) üretilebilmektedir. ${ }^{1}$ Bir rekombinant hirudin olan Lepirudin, hem serbest hem de pihtıya bağlı trombini geri dönüşümsüz inhibe eder. Hirudinler, sadece heparin ile indüklenmiş trombositopeni (HIT) ile komplike olmuş trombozis ve majör ortopedik cerrahi sonrası gelişmiş trombozis durumlarında kullanılmak üzere onaylanmıştır. Sülük tükürüğünden izole edilen diğer bir protein olan Calin’in sülük ısırığından sonra yaranın kapanmasını önlediği gösterilmiştir. Calin, hem doğrudan kollajen aracılı trombosit agregasyonunu ve aktivitesini hem de damar duvarlarında kollajene yapışık bulunan von Willebrand faktörüne bağlı trombosit agregasyonunu ve aktivitesini engeller. Bu birliktelik sülük ısırığgndan sonra kanamanın 12 saate kadar devam etmesinin biyokimyasal nedenidir. Kanamanın uzun sürmesi ile yara yatağını temizlenmesi de sağlanmakta, potansiyel olabilecek ölümcül sepsisler de engellenmektedir. Ayrica devam eden kanama, kılcal damar ağının rahatlamasını, venöz tıkanmanın azalmasını, sinir gövdelerinin ve uçlarının rahatlamasını, lenf sisteminin rahatlamasını ve lokal hemodinamiğin olumlu yönde değişmesini sağlar. ${ }^{3,4}$

Hirudinin aynı zamanda anti-enflamatuar, bakteriostatik ve analjezik etkileri de vardır. Sonuç olarak mikro dolaşım bozukluklarını ortadan kaldırır, doku ve organların damar geçirgenlik özelliklerini geri kazanmalarını sağlar, hipoksiyi ortadan kaldırır, kan basıncını düşürür ve bağışıklığı arttirir.

Günümüzde hirudoterapi, rekonstrüktif cerrahi ile uğraşan cerrahlar tarafından, özellikle cilt fleplerinde staz nedeni ile sirküle olamayan kanın temizlenmesi ve resirküle olabilmesi için kullanılmaktadır. Hirudoterapi ile venöz kan azaltılarak, uzuvları veya flepleri korumak için birikmiş kanın neden olduğu basınç azaltılabilir. Sülükler, tükürüklerinde vazodilatör, pıhtılaşma önleyici maddeler ve anestezik özellikleri olan önemli biyokimyasal maddeler içerdiklerinden bu işlem için son derece uygundur. ${ }^{2}$ (Tablo 1).

Popüler inanışın aksine, sülükler sadece yaklaşık $5 \mathrm{ml}$ kan emerler. Bununla birlikte, etkilenen bölgeye daha fazla sülük uygulanırsa etkileri artar. Toplamda 3 ila 7 gün arasında süren tedavilerinden sonra, hasarlı damarlar genellikle yeterince iyileşmiş olur. ${ }^{2}$

\begin{tabular}{|c|c|}
\hline \multicolumn{2}{|c|}{$\begin{array}{l}\text { Tablo 1: Sülük tükürrüğünde mevcut olan ve bugüne kadar en çok } \\
\text { çalışılan moleküller }{ }^{2}\end{array}$} \\
\hline - Hirudin & $\begin{array}{l}\text { Güçlü bir antikoagülan. Trombine bağlanarak } \\
\text { kan pıhtılaşmasını inhibe eder. }\end{array}$ \\
\hline $\begin{array}{l}\text { • Hyaluronidaz (yayılma } \\
\text { faktörü) }\end{array}$ & $\begin{array}{l}\text { Farmakolojik olarak aktif maddelerin dokulara, } \\
\text { özellikle eklem bölgelerine girmesini ve } \\
\text { kullanılmasını kolaylaştırır. Hyaluronidaz, } \\
\text { dokudaki geçirgenliğin ve dolaşımdaki hipok- } \\
\text { sinin düzelmesinin yanı sıra lokal şişliğin de } \\
\text { ortadan kaldırılmasını sağlar. }\end{array}$ \\
\hline - Calin & $\begin{array}{l}\text { Von Willebrand faktörünün kollajene bağl- } \\
\text { anmasını bloke ederek kanın pıhtılaşmasını } \\
\text { önler. Kollajen aracılı trombosit agregasyonunu } \\
\text { inhibe eder. }\end{array}$ \\
\hline - Destabilase & Fibrini çözücü ve trombolitik etkilere sahiptir. \\
\hline - Hirustasin & $\begin{array}{l}\text { Kallikrein, tripsin, kimo-tripsin ve nötrofilik } \\
\text { katepsin Gyyi inhibe eder. Normal kan basincı } \\
\text { seviyesinin korunmasından sorumludur. }\end{array}$ \\
\hline - Bdellinler & $\begin{array}{l}\text { Antienflamatuvar. Trypsin ve plazmini inhibe } \\
\text { eder. }\end{array}$ \\
\hline - Kloromisin & Potansiyel antibiyotik. \\
\hline - Triptaz inhibitörü & $\begin{array}{l}\text { Konak mast hücrelerinin proteolitik enzimler- } \\
\text { ini inhibe eder. }\end{array}$ \\
\hline - Eglinler & $\begin{array}{l}\text { Antienflamatuvar. Alfa-kimotripsin, kimaz, } \\
\text { substilisin, elastaz ve katepsin G'nin aktivitesi } \\
\text { engeller. }\end{array}$ \\
\hline • Faktör Xa inhibitörü & $\begin{array}{l}\text { Pıhtılaşma faktörü Xa’nın aktivitesini inhibe } \\
\text { eder (Osteoartrit ve Romatoid artrit tedavisinde } \\
\text { çok önemli rol oynarlar). }\end{array}$ \\
\hline $\begin{array}{l}\text {-Anestezik benzeri } \\
\text { maddeler }\end{array}$ & $\begin{array}{l}\text { Sülük tarafından ısırılma sırasında ağrıyı } \\
\text { azaltır. }\end{array}$ \\
\hline $\begin{array}{l}\cdot \text { Histamin benzeri } \\
\text { maddeler }\end{array}$ & $\begin{array}{l}\text { Bir vazodilatör, 1sırma bölgesinde kan akışını } \\
\text { artırır }\end{array}$ \\
\hline $\begin{array}{l}\text {-Kompleman inhibitörl- } \\
\text { eri }\end{array}$ & $\begin{array}{l}\text { Hastada doğal kompleman inhibitörleri eksik } \\
\text { ise tamamlar }\end{array}$ \\
\hline $\begin{array}{l}\text { Karboksipeptidaz- } \\
\text { A inhibitörleri }\end{array}$ & Kan akışını arttırır \\
\hline - Asetilkolin & Vazodilatör. \\
\hline - Kollajenaz & Kollajeni yıkar. \\
\hline
\end{tabular}

\section{Hirudoterapi Endikasyonları}

Geçmişte sülükler, tedavinin ardındaki etki mekanizmaları bilinmeden, sadece sorunu gidermek amacıyla çeşitli 
uygulamalar için kullanılmıştır. Günümüzde ise, sülüklerdeki aktif maddeler ile yapılmış araştırma çalışmaları bizlere tedavinin nasıl çalıştığını veya terapötik etkinliği nasıl artırdıklarını daha iyi kavramamızı sağlamaktadırlar. Hirudoterapi, günümüzde bilinen antikoagulan, vazodilatör, trombolitik, antienflamatuvar ve anestezik özellikleri nedeniyle çeşitli hastalıklarda kullanılabilir. Sülük tedavisinin kullanılabileceği endikasyonların başında plastik ve rekonstrüktif cerrahi operasyonlarında serbest ve pediküllü flep uygulamalarında post operatif gelişen venöz yetersizlikler gelir. Özellikle serbest flep uygulamalarında venöz problemler arteryel problemlere oranla çok daha sık görülmektedir. Hirudoterapi, venöz yetersizlik tedavisinde cerrahi eksplorasyona iyi bir alternatif oluşturmaktadır., Ayrıca inflamatuvar reaksiyonlarda, komplike variköz venlerde, miyokard iskemisinde (stabil veya stabil olmayan formlarda), hipertansiyon ve komplikasyonlarında (serebral vasküler krizler, tromboz ve serebral damarların embolizmi, iskemik enfarktüs, hipertansif ensefalopati gibi), infarktüs, infarktüs öncesi, infarktüs sonrası gibi kardiyolojik durumlarda, hemoroidlerde, purpura fulminansta, artroz-osteoartrit-periartrit veya romatoid artritte, varisli damarlarda, hematomlarda, dış kulak ve kronik kulak enfeksiyonlarında, katarakt, glokom gibi göz hastalıklarında, diş eti iltihabı-paradontit- dişeti ödemi gibi diş sorunlarında, sedef hastalığı gibi kronik cilt hastalıklarında, ekzematöz dermatit ve kronik ülserlerde, astım, akut rinofarenjit ve spazmodik coryza gibi solunum bozukluklarında, erkek ve kadın infertilitesi, endometriozis, parametrit gibi jinekolojik bozukluklarda kullanılabilirler. ${ }^{2}$

\section{Hirudoterapi Kontrendikasyonları}

Hirudoterapi tüm hastalarda kullanılamaz. Hastalar ilk olarak sağlık durumları açısından muayene edilmelidir. Hirudoterapi; hemofili gibi kanama bozukluklarında, Hemoglabin değeri 10mg/dl ve altında olduğunda, INR değerinin 2 ve üzerinde olduğunda, hamilelik, kanama-rüptür eğilimi olan over kistlerinde, vücut içi cerrahi operasyonların preoperatif ve postoperatif dönemlerinde, akut enfeksiyon varlığında, alt-üst gastrointestinal sistemde ka- nama varlığında, mental durumu bozuk hastalarda, akut ve kronik böbrek yetmezliğinde, HbAlc değerinin 9 ve üzerinde olması durumunda, karaciğer sirozu varlığında ve kanser tanısı almış olan hastalarda uygulanamaz. ${ }^{6}$

\section{Hirudoterapinin Cerrahide Uygulanması}

Mikrocerrahi, mikroskop altında mikroaletler kullanılarak gerçekleştirilen bir cerrahi işlem türüdür. Doku veya ampute uzuvların replantasyonunda küçük kan damarları, venleri ve arterleri anastomoz etmeyi amaçlar. Arteriyel tromboz yaygın görülmez ancak venöz tıkanma yeni nakledilen dokularda ciddi bir sorundur ve trombüs oluşumu, staz ve sonuç olarak dokunun nekrozuna kadar gidebilir. Ayrıca venöz tıkanıklık ortadan kaldırılmazsa, arteriyel dolaşımı da bozar. Bu nedenle sülüğün emme etkisinden kaynaklanan aktif kan drenajı yanı sıra, sülük tükürüğünde bulunan uzun etkili antikoagülanların varlığı ile sülüğün ayrılmasından sonra da venöz konjesyonu hafiflettiğinden sülük kullanımı tavsiye edilmektedir ${ }^{1,7}$. Isırık sonrası kanama, salgılanan biyoaktif enzim, antikoagülanlar ve vazodilatörler gibi birçok faktörün bir sonucudur. Sülüklerin hem klinik olarak hem de Doppler lazer ile kan akışını önemli ölçüde arttırdığı gösterilmiştir. Hayden ve ark. sekiz domuz greftinde sülük tedavisi sırasında, kan akışında Doppler lazer ile \%3.4'ten \%72.7’ye kadar istatistiksel olarak anlamlı bir artış olduğunu göstermişlerdir. Sülük tedavisi hastada anatomik ve klinik tam düzelme oluncaya kadar venöz dönüşü geçici olarak sağlamak için kullanılabilir ${ }^{8}$. Ancak, sülük tedavisi talimatlarıyla ilgili hiçbir uluslararası protokol oluşturulmamıştır. Mikrocerrahide tıbbi sülük uygulamasına dair tüm veriler, vaka raporlarına ve vaka serilerine dayanmaktadır ve bugüne kadar kontrollü çalışma yapılmamıştır. ${ }^{7}$

Serbest flep, pediküllü flep ve replante dokular, arteriyel yetersizlik durumlarına 13 saate kadar canlı kalabilir, ancak venöz tıkanıklıklar 3 saat içinde nekroza gidebilir. Tıbbi sülükler flepte neovaskülarizasyon gerçekleşene kadar venöz yetmezlikli dokuların tedavisinde yardımcı olabilir. ${ }^{3}$ Temmuz 2004'te FDA, sülükleri plastik ve rekonstrüktif 
cerrahi alanında tıbbi olarak kullanılmalarını onaylamıştır. Birleşik Krallık ve İrlanda Cumhuriyeti'nde 62 plastik cerrahi biriminin tamamı, bu birimlerin çoğunluğunun ameliyat sonrası sülük kullandığını göstermiştir. ${ }^{3}$

Damar tıkanıklığı rekonstrüktif cerrahide önemli bir zorluk teşkil eder. Yoğun yumuşak doku kaybı ve / veya replantasyona ihtiyaç duyulan travmatik yaralanmalar tıbbi sülük tedavileri için önemli endikasyonlardır. Ancak, hirudoterapi, sadece venöz akışın cerrahi olarak tamir edilemez olduğu tespit edildiğinde veya cerrahi kontrendike ise düşünülmelidir. Bu tür vakalarda sülük tedavisinde göz önünde bulundurulması gereken klinik bulgular, dokuda ödemin var olup olmamasını, dokunun renginin mor renk olup olmamasını ve replante dokunun sıcaklığını içerir. ${ }^{1}$

Venöz stazın ciddiyetine ve büyüklüğüne bağlı olarak, her bir tedavi için 1-10 sülük kullanılır, ancak bazı yazarlar 2 cm2'lik tıkanıklık başına bir sülük önermektedirler. ${ }^{4} \mathrm{Te}$ davinin başlangıcında, hastaların günde iki veya daha fazla seansa ihtiyacı olabilir. Günlük tedavi sayıları, önceki uygulama yerlerinden kanamalarına da bağlıdır. Kanama noktalarından sülüklerin kısa bir süre sonra ayrıldığı veya sülüklerin tam olarak tutmadığı durumlarda, daha fazla sayıda sülük ve her gün uygulanandan daha fazla sayıda seansa geçilerek daha agresif bir tedavi uygulanmalıdır. ${ }^{3}$ Sülük tedavisi, anjiyogenez ile yara sınırı boyunca venöz kapiller dönüşs sağlanana kadar kullanılır, genellikle tedavi 2-6 gün sürer. Aslında, sülük tedavisinin süresine ilişkin karar, derinin rengine, kılcal damarların dolgunluğuna ve sıan kanın rengine bakılarak ampirik olarak verilen bir karardir.

Flep takibi, Doppler ile flep stabilize olana kadar her 1-2 saatte bir, ardından 2-4 saatte bir takibi gerektirir.

Hastalar her seans sülük başına 5-15 mL kan kaybettiklerinden ve yara yeri sülük çıkarıldıktan sonra da 24 saate kadar kan sızdırmaya devam ettiğinden her 4 saatte bir hemogram, parsiyel tromboplastin zamanı ve serum biyo- kimyası çalışılmalıdır. Bununla birlikte, hematokrit kontrollerinin sayısı kullanılan sülüklerin sayısına, seansların sıklığına ve toplam tedavi süresine bağlıdır. Birçok durumda, hemoglobin seviyesi $8 \mathrm{~g} /$ dL'den düşük olduğunda hastalar kan transfüzyonu almak zorundadır. Seri fotoğraflar günlük olarak venöz tıkanıklığın yoğunluğunun değerlendirilmesine yardımcı olabilir. Tedavinin ilerleyişi de belgelenmelidir. Sülüklerin ayrılmasıyla, ısırık alanları, sülük ısırma bölgelerinden kanamayı uyarmak için izotonik sodyum klorür çözeltisi veya heparin çözeltisi (5.000 U/ $\mathrm{mL}$ ) ile ıslatılmış gazlı bezle saatte bir temizlenebilir. ${ }^{3}$

Sülük sayısı ve tedavi sıklığı oldukça değişkendir ve çeşitli hasta faktörleriyle belirlenmelidir. 1960 yılında, Derganc ve Zdraviç, venöz dolaşımlarında sıkıntı yaşanan 20 pediküllü flep vakasında, fleplere bir seferde 3-6 sülük kullanmışlar ve bunu kesin olarak ifade etmedikleri bir süre boyunca 2-3 kez tekrarlamışlar ve sonuçta fleplerin \%70’ini tamamen kurtarmayı başarmışlardır. ${ }^{9}$

Rezeksiyon ve replantasyon operasyonlarından sonra birçok başarılı sülük uygulaması belgelenmiştir. Örneğin, burunda bazal hücreli karsinom nedeni ile cerrahi işlemler geçirmiş bir kadın hastada normal kan dolaşımı başlamış ve dokuz aylık sülük tedavisinden sonra da sağlıklı bir flep varlığı görülmüştür. Medial gastrocnemius kasını ve üstündeki cildi besleyen medial sural arter için serbest flep uygulanan hastalarda venöz yetmezliği önlemek için sülük tedavisi başarıyla uygulanmıştır. Ayrıca, cerrahi flep operasyonu sonucu venöz staz gelişen altı hastada, 4-14 günlük bir tedavi rejiminin ardından tüm fleplerde başarılı olunduğu bildirilmiştir. Çalışmalar, 48 saatin sonunda hemorajik parametrelerin değişmeye başladığını, trombüsün ise 2 haftanın sonunda tamamen çözüldüğünü göstermiştir. ${ }^{7}$

Sülük tedavisinin tıkanmış dokuları açmakta iyi bir yöntem olduğu 18 olgunun 2 yll boyunca takip edildiği başka bir çalışmada da rapor edilmiştir. Bu hastaların 16’sına travma sonras1, 2'sine ise tümör rezeksiyonu sonrası re- 
konstrüktif cerrahi işlem uygulanmıştır. On üç olguda flep rekonstrüksiyonu, altı hastada toplamda yedi tane parmak replantasyonu veya revaskülarizasyonu uygulanmış, 20 vakanın 13'ünde (\% 65) sülük tedavisi ile tıkanık doku başarılı bir şekilde kurtarılmıştır (13 flepten 10’u, \%77, ve 7 parmağın 3'ü, \% 43). Pediküllü fleplerde başarı oranı çok iyi 6/6 (\%100) iken, parmak revaskülarizasyonlarında 2/3 (\%67), fakat parmağın yeniden dikilmelerinde 1/4 (\%25) ve serbest fleplerde zayıf (\%0) olarak tespit edilmiş, sülüklerin venöz konjesyonda tercih edilebilecek yararlı bir araç olduğu, pediküllü fleplerde serbest fleplere veya parmak replantasyonundan çok daha fazla fayda görülebileceği gösterilmiştir. ${ }^{10}$

Diğer bir çalışmada, uzun süre turnikede kalmış iskemik bir parmağı kurtarmak için sülük uygulaması tarif edilmektedir. Birinci günün sonunda parmak klinik olarak iyileşmeye başlamış, venöz staz azalmış ve yaradan kanın daha rahat kanadığı görülmüştür. Sülük tedavisinin devam ettiği 3. günde, hafif de olsa mobilizasyon başladığı görülünce fizyoterapistlere sevk edilmiştir. Tedavinin 7. gününde, hasta parmağın üstündeki dokuda iyileşme ve hassasiyet tanımlamıştır ${ }^{11}$. Sülüklerin, faydalı bir etkiye sahip olması için her 8 saatte bir uygulanması gerektiğini bildirmişler, sülük tedavisinin dezavantajı olarak, sülük tükürüğünde Aeromonas spp. gibi potansiyel olarak ölümcül hastalıklara neden olabilecek patojenlerin varlığından dolayı her zaman uygun antibiyotik tedavisi ile birlikte uygulanması gerektiğini vurgulamışlardır. ${ }^{11}$

2004 yılında Tuncali ve arkadaşları, venöz tamir yapamadıkları class IIC halka avulsiyon hasarı (arteriyel arz bozulmamış, venöz drenaj bozulmuş) olan 2 vakada 7 ila 10 gün boyunca günde 4 ila 6 sülük uygulamışlar ve her ikisinde de parmakların işlevlerini geri kazandıklarını bildirmişlerdir. $^{12}$

Bir vaka serisinin metaanalizinde, serbest ve pediküllü flep tedavilerinde sülüklerin uygulandığı 108 vaka gözden geçirilmiş ve 89'unda (\%83) başarılı sonuçların elde edildiği- ni bildirilmiştir. ${ }^{13}$

Sülük kullanan çene-yüz plastik cerrahlar deneyimlerinde, daha fazla dokunun korunduğunu, hızlı ve mükemmel fonksiyonel iyileşmenin sağlandığını, nadir postoperatif komplikasyonların geliştiğini ve daha başarılı kozmetik sonuçların elde edildiğini belirtmişlerdir. Üstelik, sülük tükürügünde immünmodülatör özellikte protein yapıda moleküller bulunduğundan, örneğin, çene rekonstrüksiyonu ameliyatı sonrasında X-ışını tedavisi alan hastalarda, immünosupresyonu önemli ölçüde önlediği görülmüştür. $\mathrm{Bu}$ nedenle, bu gibi vakalarda cerrahlar kombine hirudoterapi kullanılmasını önermektedirler. ${ }^{14}$

Üroloji de dorsal penil ven ve penil arterlerin reanastomozunda mikrocerrahi teknikleri kullanıldığında daha az cilt ve greft kaybının yaşandığı, daha yüksek oranda normal duyum ve ereksiyonun tespit edilebildiği bilinmektedir. Çok daha az komplikasyon yaşandığı için mikrocerrahi tekniğinin kullanılması artık birçok hastanede standart haline gelmiştir. Ancak mikrocerrahi düzeyde ameliyat için ekipman eksikliği olan ortamlar veya penil dorsal venin ciddi şekilde hasar gördüğü vakalar olabilir. Venöz tıkanıklıktan kaynaklanan greft komplikasyonları plastik ve rekonstrüktif cerrahi literatüründe detaylı bir şekilde anlatılmıştır. Greftin "take” (alma) döneminde venöz tıkanıklık azaltılırsa iskemik komplikasyonlar büyük ölçüde azaltılabilir. 1996 yılında Michael Mineo ve arkadaşlarının sunduğu bir vakada penisi tamamen kesilmiş olan 32 yaşındaki bir erkekte, postoperatif venöz tıkanıklığı gidermek için sülük kullandıklarını ilk defa bildirmişlerdir. Mikrocerrahi kullanılmadan yapılan operasyonda penil replantasyon, hirudoterapi eşliğinde çok başarılı olmuştur. Sülükle tedavi edilen hastalarda ödemin görülmediği ve boşalma, duyu, ereksiyon gibi normal işlevlerin devam ettiği görülmüştür. ${ }^{15}$

\section{Yan Etkiler ve Komplikasyonları}

Modern sülük tedavisi, genellikle güvenli ve iyi tolere edilebilen bir tedavi şekli olarak kabul edilir. Onay formunu 
imzalamayı reddeden, antibiyotik ile profilaktik tedaviyi reddeden veya kan transfüzyonunu reddeden hastalara hirudoterapi başlanmamalıdır.

Birkaç saat boyunca devam eden Y-şekilli ısırık bölgesinin hafifçe kaşınması, sülük tedavisinin en sık karşılaşılan (\%37.3-75) yan etkisidir. Etkilenen cilt bölgelerine kısa süreli soğuk kompres veya antiallerjik jel (Dimentinden maleat gibi) kullanılabilir. Ciddi genel kaşıntı vakalarında, topikal kortikosteroidler ve oral antihistaminikler reçete edilmelidir. Bölgesel lenfadenitlerde hafif şişlik, bölgesel lenf nodu ağrısı, subfebril sıcaklık tedavi edilen hastaların \%6.4-13.4'ünde görülebilir. Sülükler estetik açıdan önemli ince deriye uygulandığında skar oluşabilir, kozmetik problemler yaşanabilir.

Sülük tedavisi ile aşırı kanama olabilir; doğrudan basınç veya topikal trombin uygulanarak kontrol edilebilir. Ancak kanama eğilimi olan hastalarda, ciddi kansızlığı olan hastalarda veya antikoagülan veya trombosit inhibe edici ilaçlar alan hastalarda transfüzyon ihtiyacı doğabilir. Kan transfüzyonu hemoglobin $<8 \mathrm{~g} / \mathrm{dL}$ seviyesine inerse verilir. Genellikle, kan kaybını telafi etmek için 3-6 ünite kan kullanılır. ${ }^{15}$

Venöz tıkanıklık tespit edildikten ve hasta sülük tedavisi almayı kabul ettikten sonra, hastanın tedavinin yararları ve potansiyel riskleri hakkında bilgilendirilmesi önemlidir. Hirudoterapi başlamadan önce hastalardan veya ebeveynlerinden yazılı bir onam alınmalıdır.

Sülük tedavisi öncesinde, sülüklerin sindirim sisteminde simbiyoz yaşayan ve komplikasyonlara yol açabilen Aeromonas bakterileri için antibiyotik profilaksisinin başlatılması gerektiği konusunda genel bir fikir birliği vardır ${ }^{3}$. Aeromonas türleri, ikinci ve üçüncü kuşak sefalosporinlere, ürokinolonlara, trimetoprim-sülfametoksazole, tetrasikline ve aminoglikozitlere karşı duyarlı, penisilin, ampisilin, birinci kuşak sefalosporin ve eritromisine karşı dirençlidir. Hastalar sülük tedavisinin her günü 500 mg siprofloksasin gibi anti-Aeromonas antibiyotik ile tedavi edilmelidirler ${ }^{3}$. Aeromonas enfeksiyonları akut (24 saat içinde) veya gecikmeli bir şekilde (26 güne kadar) ortaya çıkabilir. Aeromonas enfeksiyonları küçük bir yara enfeksiyonundan sepsise kadar ilerleyebilen apse, gastroenterit veya selülit ile sonuçlanabilecek yelpazede değişik klinik sonuçlar sergileyebilir². Ayrıca lokal doku hasarı ile flep yetmezliğine, hastanede kalış süresinin uzamasına, ek antibiyotiklere ve hatta ölüme neden olabilir. Ağır enfeksiyonlar agresif debridman ve yüksek doz antibiyotiklerle tedavi edilmelidir. Enfekte vakalarda bildirilen flep sağkalımı \%30'dan daha azdır. Sülükle ilişkili Aeromonas enfeksiyonlarının immünsupresif hastalarda daha sık geliştiğini vurgulamak gerekir ${ }^{4}$. Enfeksiyon, sülük tedavisinin ciddi bir olumsuz etkisi olduğundan, hasta ve aileye ayrıca erken belirti ve semptomları gözlemlemesi ve bildirmesi talimatı verilmelidir. $^{2}$

\section{SONUÇ}

Hirudoterapi, güçlü biyokimyasal etkilere sahip, çağlar boyunca popüler kalmış geleneksel bir tedavi yöntemidir. Yakın geçmiş zamana kadar bilimsel olmayan, tercih edilmeyen bir tedavi yöntemi gibi görünse de şimdilerde çok sayıda bilimsel çalışma ve vaka raporlarıyla kanıtlanarak ve desteklenerek çağdaş tıbba geri dönmüştür. Uygulaması kolay, yan etkileri az ve uygun maliyettedir. Plastik ve rekonstrüktif cerrahi alanında sülük tedavisine, kendi başına bir tedavi yöntemi olarak değil multidisipliner tedavi yaklaşımının bir parçası olarak yaklaşılmalıdır. Bu nedenle kullanımının optimize edilmesi için daha fazla çaba gösterilmeli, daha fazla araştırmalar yapılmalıdır. 
Journal of BSHR 2019;3(Özel Say1):47-54

TRAK. Hirudoterapi ve Cerrahide Kullanımı

\section{Kaynaklar}

1. Houschyar KS, Momeni A, Maan ZN, Pyles MN, Jew OS, Strathe M, et al. Medical leech therapy in plastic reconstructive surgery. Wien Med Wochen. 2015;165:419-25.

2. Abdullah S, Dar LM, Rashid A, Tewari A. Hirudotherapy/Leech therapy. Applications and indications in surgery. Arch Clin Exp Surg. 2012; 1(3): 172-180.

3. Mumcuoglu KY. Recommendations for the use of leeches in reconstructive plastic surgery. Evid Based Complement Alternat Med. 2014; 2014:205929.

4. Green PA, Shafritz AB. Medicinal leech use in microsurgery. J Hand Surg Am. 2010; 35(6):1019-21.

5. Whitaker IS, Izadi D, Oliver DW, et al. Hirudo medicinalis and the plastic surgeon. $\mathrm{Br} J$ Plast Surg. 2004; 57(4): 348-53.

6. Medipol Üniversitesi, Hirudoterapi Sertifikah Eğitim Programı, Ders Notları, 2008.

7. Abdualkader AM, Ghawi AM, Alaama M, et al. Leech Therapeutic Applications: Indian. J Pharm Sci. 2013; 75(2):127-37.

8. Hayden RE, Phillips JG, McLear PW. Leeches. Objective monitoring of altered perfusion in congested flaps. Arch Otolaryngol Head Neck Surg. 1988; 114(12):1395-9.
9. Derganc $M, Z$ dravic $F$. Venous congestion of flaps treated by application of leeches. Br J Plast Surg. 1960; 13:187-19

10. Butt AM, Ismail A, Lawson-Smith M, Shahid M, Webb J, Chester DL. Leech therapy for the treatment of venous congestion in flaps, digital re-plants and revascularizations -A two-year review from a regional centre. J Ayub Med Coll Abbottabad. 2016; 28:219-23.

11. Durrant C, Townley WA, Ramkumar S, Khoo CT. Forgotten digital tourniquet: salvage of an ischemic finger by application of medicinal leeches. Ann R Coll Surg.2006; 88:462-464.

12. Tuncali D, Terzioglu A, Cigsar B, Aslan G. The value of medical leeches in the treatment of class IIC ring avulsion injuries: report of 2 cases. $d$ Hand Surg Am. 2004; 29:943-946.

13. de Chalain TM. Exploring the use of the medicinal leech: a clinical risk-benefit analysis. J Reconstr Microsurg.1996;12:165-172.

14. Gilyova OS, Korobeinikova GA, Gilyova ES et al. The achievements of modern medicine in systemic hirudotherapy. 1999; Russ J Biomech 3:68-77.

15. Mineo M, Jolley T, Rodriguez G. Leech therapy in penile replantation: A case of recurrent penile self-amputation. Urology. 2004; 63:981-3. 